\title{
Mechanism of Adsorption of Cadmium and Lead lons by Iron-activated Biochar
}

\author{
Liqiang Cui, ${ }^{\mathrm{a}}$ Tianming Chen, ${ }^{\mathrm{a}}$ Chuntao Yin, ${ }^{\mathrm{a}}$ Jinlong Yan, ${ }^{\mathrm{a}, *}$ James A. Ippolito, ${ }^{\mathrm{b}}$ and \\ Qaiser Hussain $^{\mathrm{c}}$
}

\begin{abstract}
Heavy metal removal from aqueous matrices may help reduce disease and cancer incidences. In this study, reed biochar (RBC) and RBC

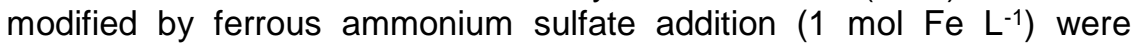
compared for potential $\mathrm{Cd}$ and $\mathrm{Pb}$ removal from varying $\mathrm{pH}$ aqueous solutions. Surface functional groups were identified using Fourier transform infrared (FTIR) analysis, and their surface physicochemical structure was observed using scanning electron microscopy-energy dispersive spectrometry (SEM-EDS). Batch experiments showed that the modified-reed biochar (MRBC) had greater $\mathrm{Cd}$ and $\mathrm{Pb}$ removal capacities over a wide $\mathrm{pH}$ range (1 to 8$)$, as well as greater metal sorption capacities compared to RBC. Metal reaction kinetics occurred relatively quickly (i.e., within $60 \mathrm{~min}$ ), and Langmuir modeling suggested that $\mathrm{Cd}$ and $\mathrm{Pb}$ removal by MRBC was maximized at $2.97 \mathrm{mg} \mathrm{g}^{-1}$ and $17.5 \mathrm{mg} \mathrm{g}^{-1}$ at $45^{\circ} \mathrm{C}$, respectively. The MRBC effectively sorbed $\mathrm{Cd}$ and $\mathrm{Pb}$ likely due to associations with functional groups modified by the $\mathrm{Fe}$ addition. In the future, MRBC may be used as an efficient and ecofriendly adsorbent for $\mathrm{Cd}$ and $\mathrm{Pb}$ removal from aqueous solutions and may help reduce water-borne issues associated with metal contamination.
\end{abstract}

Keywords: Biochar; Reed biochar; Heavy metals; Amendment; Contaminated water

Contact information: a: School of Environmental Science and Engineering, Yancheng Institute of Technology, No. 211 Jianjun East Road, Yancheng 224051, China; b: Department of Soil and Crop Sciences, Colorado State University, Fort Collins, Colorado 80523, USA; c: Department of Soil Science and Soil Water Conservation, PirMehr Ali Shah Arid Agriculture University, Rawalpindi, Pakistan;

*Corresponding author: yjlyt4788@126.com

\section{INTRODUCTION}

Industrial effluents from smelting facilities, dye factories, and paper mills contain various heavy metals that can be responsible for surface water, groundwater, and soil contamination. Once in water or soil, heavy metals can be transferred and accumulated into edible plant parts, becoming part of the food chain, and thus pose a threat to public health (Khan et al. 2008). Specifically, heavy metals such as cadmium $(\mathrm{Cd})$ and lead $(\mathrm{Pb})$, are well known pollutants that cause diseases such as itai-itai, Minamata disease, and various cancers (Harada 1995; Bolognesi et al. 1999; Inaba et al. 2005; Khan et al. 2014). Because of the negative connotation between heavy metals, health risk, and the environment, several amendment methods and technologies have been used for the removal/stabilization of heavy metals from wastewaters and soil (Bogusz et al. 2015). Traditional metal removal methods include chemical precipitation, ion exchange, and membrane separation processes (Chen et al. 2015). Unfortunately, some of these methods and technologies require special facilities to remove such metals as well as expensive chemicals to remove these metals or follow more complex processes, making traditional 
metal removal methods less attractive for environmental cleanup. Simpler heavy metal sorbents are needed that ideally come from local sources near local heavy metal problem areas.

Biochar, a carbon-rich byproduct derived from biomass pyrolysis under oxygenlimited conditions (Wang et al. 2016), shows significant promise as a heavy metal sorbent (Mohan et al. 2014; Kim et al. 2015; Ippolito et al. 2017). Ippolito et al. (2017) found that pine biochar can reduce bioavailable soil metals $(\mathrm{Cd}, \mathrm{Cu}, \mathrm{Pb}$, and $\mathrm{Zn}$ ), which were extracted with $0.01 \mathrm{M} \mathrm{CaCl}_{2}$. Uchimiya et al. (2010) used biochar to immobilize several metals $(\mathrm{Cu}, \mathrm{Cd}, \mathrm{Ni}$, and $\mathrm{Pb})$ from an aqueous solution. Pig and cow manure biochars have been demonstrated to be efficient sorbents for removing $\mathrm{Cu}$ (II), $\mathrm{Zn}$ (II), $\mathrm{Cd}(\mathrm{II})$, and $\mathrm{Pb}$ (II) ions from an aqueous solution (Kołodyńska et al. 2012). Bamboo biochar has been shown to be an efficient sorbent for $\mathrm{Pb}$ and $\mathrm{Cd}$ removal from aqueous solutions. Also, the quantity of $\mathrm{Pb}$ sorbed is reduced when both metals are present together in solution (Han et al. 2017), suggesting that competitive metal sorption likely occurs on biochars. These studies utilized biochars in a non-activated (i.e., as-is) state, yet studies have shown that activating biochar may increase heavy metal sorption over nonactivated biochars.

Karunanayake et al. (2018) found that $\mathrm{Fe}_{3} \mathrm{O}_{4}$-magnetized Douglas fir biochar is effective sorbed $\mathrm{Cd}$ and $\mathrm{Pb}$ and easy separated from aqueous solution. Steam-activated $\left(800{ }^{\circ} \mathrm{C}\right.$ for $\left.3 \mathrm{~h}\right)$ and $\mathrm{KOH}$-treated $(1.3 \mathrm{M})$ biochars have been shown to successfully remove $\mathrm{Cu}$ from solutions (Ippolito et al. 2012). Similarly, modified biochars (nanoscale zerovalent, $\mathrm{NaOH}$, and $\mathrm{Zn}$ ion-modified biochars) produced from various metal iontreated biomass materials are used as adsorbents for heavy metal $(\mathrm{Cd}, \mathrm{Pb}$, As, etc.) removal from water (Wang et al. 2017). Biochar modification via activation can increase surface area, ligand functional group presence, or the amount of $\mathrm{C}=\mathrm{C} \pi$ electrons available (Uchimiya et al. 2010; Ippolito et al. 2012; Qiao et al. 2015), all of which play a role in improving heavy metal sorption.

Reed (Phragmites australis), a halophyte in coastal areas, is widespread in many saline-alkali lands and aquatic ecosystems in China (Zheng et al. 2013). Reed has tolerance to salts and floods, is used to improve soil conditions, and grows relatively quickly, making it a suitable raw material for biochar production (Roberts et al. 2010). In this study, a modified reed biochar was synthesized via pretreatment with ferrous ammonium sulfate $\left[\left(\mathrm{NH}_{4}\right)_{2} \mathrm{Fe}\left(\mathrm{SO}_{4}\right)_{2}\right]$ for the eventual removal of solution-borne $\mathrm{Cd}$ and $\mathrm{Pb}$.

It was hypothesized that biochar pretreatment with a strong reducing agent, $\left(\mathrm{NH}_{4}\right)_{2} \mathrm{Fe}\left(\mathrm{SO}_{4}\right)_{2}$, could be a precursor for amorphous iron oxide (FeOx) formation, which following pyrolysis could enhance biochar reactive surfaces and improve biochar's ability to remove $\mathrm{Cd}$ and $\mathrm{Pb}$ from a solution. Thus, the objective of this study is to investigate the efficacy of reed-derived biochar (RBC) compared to modified reedderived biochar (MRBC) for removing and retaining $\mathrm{Cd}$ and $\mathrm{Pb}$ from an aqueous solution. Finally, biochar $\mathrm{Cd}$ and $\mathrm{Pb}$ sorption mechanisms are elucidated by examining functional group presence using Fourier transform infrared (FTIR) and microscopic physicochemical structure using scanning electron microscopy-energy dispersive X-ray spectroscopy (SEM-EDS). 


\section{EXPERIMENTAL}

\section{Materials}

Reed (Phragmites australis) was collected from a beach at Yancheng in Jiangsu, China. The collected reed samples were washed with tap water, triple rinsed with distilled water, dried at $60{ }^{\circ} \mathrm{C}$, and then powder ground. Biochar was made from reed powder pyrolyzed at $450{ }^{\circ} \mathrm{C}$ for $4 \mathrm{~h}$ with a linear rise of $10{ }^{\circ} \mathrm{C} \mathrm{min}^{-1}$ in a vacuum tube furnace (NBD-O1200; Nobody Material Science and Technology Co., Ltd., Henan, China) and in a nitrogen gas environment $\left(500 \mathrm{~mL} \mathrm{~min}^{-1}\right)$. After pyrolysis and cooling, biochar was ground passing through $0.15 \mathrm{~mm}, 0.18 \mathrm{~mm}, 0.25 \mathrm{~mm}, 0.42 \mathrm{~mm}, 0.85 \mathrm{~mm}$, and $2 \mathrm{~mm}$ sieves.

The modified reed biochar (MRBC) was made by soaking $250 \mathrm{~g}$ of powder reed biomass in $1 \mathrm{~L}$ of $1 \mathrm{M}\left(\mathrm{NH}_{4}\right)_{2} \mathrm{Fe}\left(\mathrm{SO}_{4}\right)_{2}$ in a 1.5 - $\mathrm{L}$ plastic bottle with a neutral $\mathrm{pH}$. This solid to liquid ratio filled the plastic bottle with no head space for air. Next, the mixture was shaken at $180 \mathrm{rpm}$ for $24 \mathrm{~h}$ at $25{ }^{\circ} \mathrm{C}$, and then the reed biomass was separated via filtration. Afterwards, the material was washed with deionized water until the filtrate was free of Fe with loretin testing (Johansson et al. 2016). The treated, rinsed reed biomass was oven-dried to a constant weight $\left(24 \mathrm{~h}, 60^{\circ} \mathrm{C}\right)$, converted to MRBC by slow pyrolysis as the RBC methods, and sieved into the various size fractions described above.

\section{Methods}

Basic biochar properties of the $0.15-\mathrm{mm}$ size fraction are presented in Table 1 , and were analyzed according to procedures described by Lu (2000), including pH (glass electrode method), carbon (potassium dichromate titrimetric method), total $\mathrm{N}$ (Kjeldahl method), total $\mathrm{P}\left(\mathrm{H}_{2} \mathrm{SO}_{4} / \mathrm{HClO}_{4}\right.$ digestion followed by the molybdenum blue method), total $\mathrm{K}$ (flame atomic absorption method), and total $\mathrm{Cd}$ and $\mathrm{Pb}$ (flame atomic absorption spectrometry, FAAS. The specific surface area (SSA) was determined by the BrunauerEmmett-Teller (BET) method with a surface area and porosity analyzer (ASAP 2460; Micromeritics, Norcross, GA, USA). Biochar cation exchange capacity (CEC) was measured via the sodium acetate exchange method. Briefly, the biochar was mixed with an excess of sodium acetate solution, resulting in an exchange of the added sodium cations for the matrix cations. Next, the biochar was washed with 95\% alcohol. An ammonium acetate solution was then added, which replaced the adsorbed sodium with ammonium. Finally, the displaced $\mathrm{Na}$ was determined through atomic sorption spectroscopy (AAS; TAS-986; Beijing Persee General Instrument Co., Ltd., Beijing, China). Biochar functional groups, such as $-\mathrm{OH}$ and $\mathrm{C}=\mathrm{O}$, were identified using a FTIR spectrometer (Nexus-670; Thermo Fisher Scientific, Waltham, MA, USA) via the KBr (KBr:biochar, 100:1) tablet method.

Table 1. Basic Properties of the $0.15-\mathrm{mm}$ Size Fraction of RBC and MRBC.

\begin{tabular}{|c|c|c|c|c|c|c|c|c|c|}
\hline & $\mathrm{pH}$ & $\mathrm{SSA}^{\dagger}$ & Carbon & $\mathrm{N}$ & $\mathrm{P}$ & $\mathrm{K}$ & $\mathrm{CEC}$ & $\mathrm{Cd}$ & $\mathrm{Pb}$ \\
\hline & $\left(\mathrm{H}_{2} \mathrm{O}\right)$ & $\left(\mathrm{m}^{2} \mathrm{~g}^{-1}\right)$ & \multicolumn{5}{|c|}{$\left(\mathrm{g} \mathrm{kg}^{-1}\right)$} & $\left(\mathrm{cmol}^{+} \mathrm{kg}^{-1}\right)$ & \multicolumn{2}{|c|}{$\left(\mathrm{mg} \mathrm{kg}^{-1}\right)$} \\
\hline Reed & $/$ & $/$ & 402.5 & 4.13 & 2.08 & 3.92 & $/$ & $\mathrm{ND}$ & $\mathrm{ND}$ \\
\hline RBC & 8.50 & 5.6 & 879.1 & 10.48 & 26.32 & 20.35 & 4.32 & 0.01 & 2.17 \\
\hline MRBC & 10.53 & 10.5 & 812.5 & 55.65 & 34.01 & 19.56 & 9.34 & 0.02 & 3.96 \\
\hline
\end{tabular}

† SSA: specific surface area; CEC: cation exchange capacity; the $\mathrm{N}, \mathrm{P}, \mathrm{K}, \mathrm{Cd}$, and $\mathrm{Pb}$ concentrations are expressed as total concentrations; ND: not detected. 
Cadmium (as $\mathrm{CdCl}_{2}$ ) and $\mathrm{Pb}$ (as $\left[\mathrm{Pb}\left(\mathrm{NO}_{3}\right)_{2}\right]$ ) (chemicals purchased from Sinopharm Chemical Reagent Co., Ltd., Shanghai, China) sorption onto the biochars was determined as a function of solution $\mathrm{pH}$. The $0.15-\mathrm{mm} \mathrm{RBC}$ or MRBC size fraction was used (as this fraction sorbed the greatest metal concentrations as per the above experiment) with $0.10 \mathrm{~g}$ biochar mixed with $50 \mathrm{~mL}$ of $0.01 \mathrm{M} \mathrm{NaNO}_{3}$ solution containing either $5 \mathrm{mg} \mathrm{Cd} \mathrm{L}^{-1}$ or $50 \mathrm{mg} \mathrm{Pb} \mathrm{L}^{-1}$. The solution $\mathrm{pH}$ was either $1,2,3,4,5,6,7$, or 8 , which was adjusted using either $0.1 \mathrm{~mol} \mathrm{~L}^{-1} \mathrm{HCl}$ or $\mathrm{NaOH}$ before shaking. All treatments were replicated three times. The solutions were then shaken for $2 \mathrm{~h}$ at $180 \mathrm{rpm}$, filtered, and the filtrate $\mathrm{Cd}$ and $\mathrm{Pb}$ concentrations were determined by AAS.

Next, $\mathrm{Cd}$ and $\mathrm{Pb}$ sorption experiments were conducted using both $\mathrm{RBC}$ and $\mathrm{MRBC}$ in batch equilibrium experiments at $25{ }^{\circ} \mathrm{C}$. First, $\mathrm{Cd}$ and $\mathrm{Pb}$ sorption onto the various biochar size fractions (e.g., 0.15, 0.18, 0.25, 0.42, 0.85, and $2 \mathrm{~mm}$ ) was determined to identify the ideal size fraction for the greatest metal sorption capability. Three $0.10 \mathrm{~g} \mathrm{RBC}$ or MRBC samples were mixed with $50 \mathrm{~mL}$ of $0.01 \mathrm{M} \mathrm{NaNO}_{3}$ solution containing either $5 \mathrm{mg} \mathrm{Cd} \mathrm{L}^{-1}$ or $50 \mathrm{mg} \mathrm{Pb} \mathrm{L}^{-1}$ with a natural $\mathrm{pH}$ (approximately 7). The mixtures were shaken for $2 \mathrm{~h}$ at $180 \mathrm{rpm}$, filtered, and the filtrate $\mathrm{Cd}$ and $\mathrm{Pb}$ concentrations were determined by AAS.

Next, the biochar dose necessary to maximize $\mathrm{Cd}$ or $\mathrm{Pb}$ sorption was determined. The $0.15-\mathrm{mm} \mathrm{RBC}$ or MRBC size fraction was again used, with either $0.08,0.10,0.20$, 0.40 , or $0.80 \mathrm{~g}$ biochar mixed with $50 \mathrm{~mL}$ of $0.01 \mathrm{M} \mathrm{NaNO}_{3}$ solution containing either 5 $\mathrm{mg} \mathrm{Cd} \mathrm{L} \mathrm{C}^{-1}$ or $50 \mathrm{mg} \mathrm{Pb} \mathrm{L}^{-1}$ with a natural $\mathrm{pH}$ (approximately 7). All treatments were replicated three times. The mixtures were shaken for $2 \mathrm{~h}$ at $180 \mathrm{rpm}$, filtered, and the filtrate $\mathrm{Cd}$ and $\mathrm{Pb}$ concentrations were determined by AAS.

Sorption kinetics were then determined only for the MRBC. Three, $0.10 \mathrm{~g}$ biochar samples from the $0.15-\mathrm{mm}$ size fraction were mixed with $50 \mathrm{~mL}$ of $0.01 \mathrm{M} \mathrm{NaNO}$

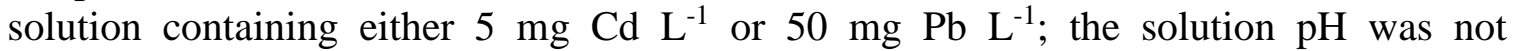
controlled. These experiments were performed at $25^{\circ} \mathrm{C}, 35^{\circ} \mathrm{C}$, and $45^{\circ} \mathrm{C}$ in a water bath with varying shaking times $(0,10,30,60,120,240$, and $480 \mathrm{~min})$. All of the solutions were then filtered and analyzed for their $\mathrm{Cd}$ and $\mathrm{Pb}$ concentrations using AAS.

Biochar equilibrium isotherms were also only determined for the 0.15-mm MRBC size fraction. Three, $0.10 \mathrm{~g}$ biochar samples were mixed with $50 \mathrm{~mL}$ of $0.01 \mathrm{M} \mathrm{NaNO}_{3}$ solution containing increasing $\mathrm{Cd}\left(0,1,2,8,10,20\right.$, and $\left.40 \mathrm{mg} \mathrm{Cd} \mathrm{L}^{-1}\right)$ or $\mathrm{Pb}(0,20,40$, 80 , and $\left.160 \mathrm{mg} \mathrm{Pb} \mathrm{L}^{-1}\right)$ concentrations. The mixtures were shaken for $2 \mathrm{~h}$ at $180 \mathrm{rpm}$ and at $25{ }^{\circ} \mathrm{C}, 35{ }^{\circ} \mathrm{C}$, and $45{ }^{\circ} \mathrm{C}$ in a water bath; the solution $\mathrm{pH}$ was not controlled. These metal concentrations bracketed $\mathrm{Cd}$ and $\mathrm{Pb}$ concentrations that are found in industrial wastewaters (e.g., Singh et al. 2016). All of the solutions were then filtered and the filtrate $\mathrm{Cd}$ and $\mathrm{Pb}$ concentrations were determined by AAS.

Heavy metal RBC and MRBC sorption rate behaviors were evaluated using the pseudo-first-order (1) and pseudo-second-order (2) model equations as follows,

$$
\begin{aligned}
& \ln \left(Q_{e}-Q_{t}\right)=\ln Q_{e}-K_{1} t \\
& \frac{t}{Q_{t}}=\frac{t}{Q_{e}^{2} \times K_{2}}+\frac{t}{Q_{e}}
\end{aligned}
$$

where $Q_{\mathrm{e}}$ and $Q_{\mathrm{t}}$ are the amounts of the heavy metal sorption capacity per unit weight of biochar $\left(\mathrm{mg} \mathrm{g}^{-1}\right)$ corresponding to the equilibrium and time $t$ (min), $K_{1}$ is the pseudo-first- 
order constant $\left(\mathrm{h}^{-1}\right), K_{2}$ is the pseudo-second-order constant $\left(\mathrm{g} \mathrm{mg}^{-1} \mathrm{~h}^{-1}\right)$, and the $t$ is time (min).

The prediction models of Freundlich (3) and Langmuir (4) were also employed,

$$
\begin{aligned}
& \ln Q_{e}=\ln K_{F}+\frac{1}{n} \times \ln C_{e} \\
& Q_{e}=\frac{C_{e} \times K_{L} \times Q_{\max }}{1+C_{e} \times K_{L}}
\end{aligned}
$$

where $C_{\mathrm{e}}$ is the heavy metal solution concentration $\left(\mathrm{mg} \mathrm{L}^{-1}\right)$ after $2 \mathrm{~h}, Q_{\max }$ is the maximum adsorption capacity $\left(\mathrm{mg} \mathrm{g}^{-1}\right), K_{\mathrm{F}}$ is the Freundlich parameter related to sorption capacity, $K_{\mathrm{L}}$ is the Langmuir constant $\left(\mathrm{L} \mathrm{mg}^{-1}\right)$ that estimates the binding strength between the surface and the sorbate, and $n$ is an empirical constant.

Finally, the particle composition of RBC and MRBC was determined via scanning electron microscopy equipped with energy dispersive X-ray spectroscopy (SEM-EDS; Nova Nano SEM 450; FEI Co., Hillsboro, OR, USA). Biochar SEM-EDS analyses were performed on non-coated particles, directly mounted on an Al SEM-stub using doublesided adhesive copper conducting tape (3M®, Oxford Instruments, Abingdon, UK). The SEM operational conditions used were a $15-\mathrm{kV}$ accelerating voltage at 40 to $90000 \times$ magnifications, with back-scattered electrons collected under low vacuum. The EDS elemental spectra were collected from specific locations of interest on both the RBC and MRBC particles.

\section{RESULTS AND DISCUSSION}

\section{Characterization of BC}

Functional groups present on the RBC and MRBC were compared to that of the powder ground reed feedstock using FTIR (Fig. 1). The reed and modified reed biochar spectra were different when compared to the reed feedstock, with the FTIR spectra reflecting the presence of functional groups due to dehydration, decarbonylation, depolymerisation, and fragmentation during pyrolysis and the activation process (Kan et al. 2016). The presence of intermolecular $\mathrm{O}-\mathrm{H}$ from the dehydration of cellulosic and ligneous components was observed at 3500 to $3200 \mathrm{~cm}^{-1}$. The abundance of C-H (2977 to $\left.2921 \mathrm{~cm}^{-1}\right)$, aliphatic C-O-C $\left(1050 \mathrm{~cm}^{-1}\right)$, and alcohol-OH $\left(1158 \mathrm{~cm}^{-1}\right)$ was attributed to the presence of cellulose.

The increased peak intensities of -OH (3345 to $3426 \mathrm{~cm}^{-1}$ ) and C-H (3032 to 2858 $\mathrm{cm}^{-1}$ and 1452 to $\left.1319 \mathrm{~cm}^{-1}\right)$ and the decreased intensity of aliphatic C-O-C $\left(1050 \mathrm{~cm}^{-1}\right)$ with modified biochar were consistent with dehydration reactions and functional groups changes that occur with temperature changes during the pyrolysis process (Qian et al. 2016). Similar to these results, Wang et al. (2015) reported that modified-biochar contains more oxygen-containing functional groups and a larger surface area than unmodified biochar. Modified biochar functional groups, such as $\mathrm{C}-\mathrm{O}-\mathrm{C},-\mathrm{OH}, \mathrm{C}-\mathrm{C}$, etc., and special microstructures play a vital role in metal sorption by binding or complexing Cd and Pb (Cui et al. 2013, 2014; Xu et al. 2013). 


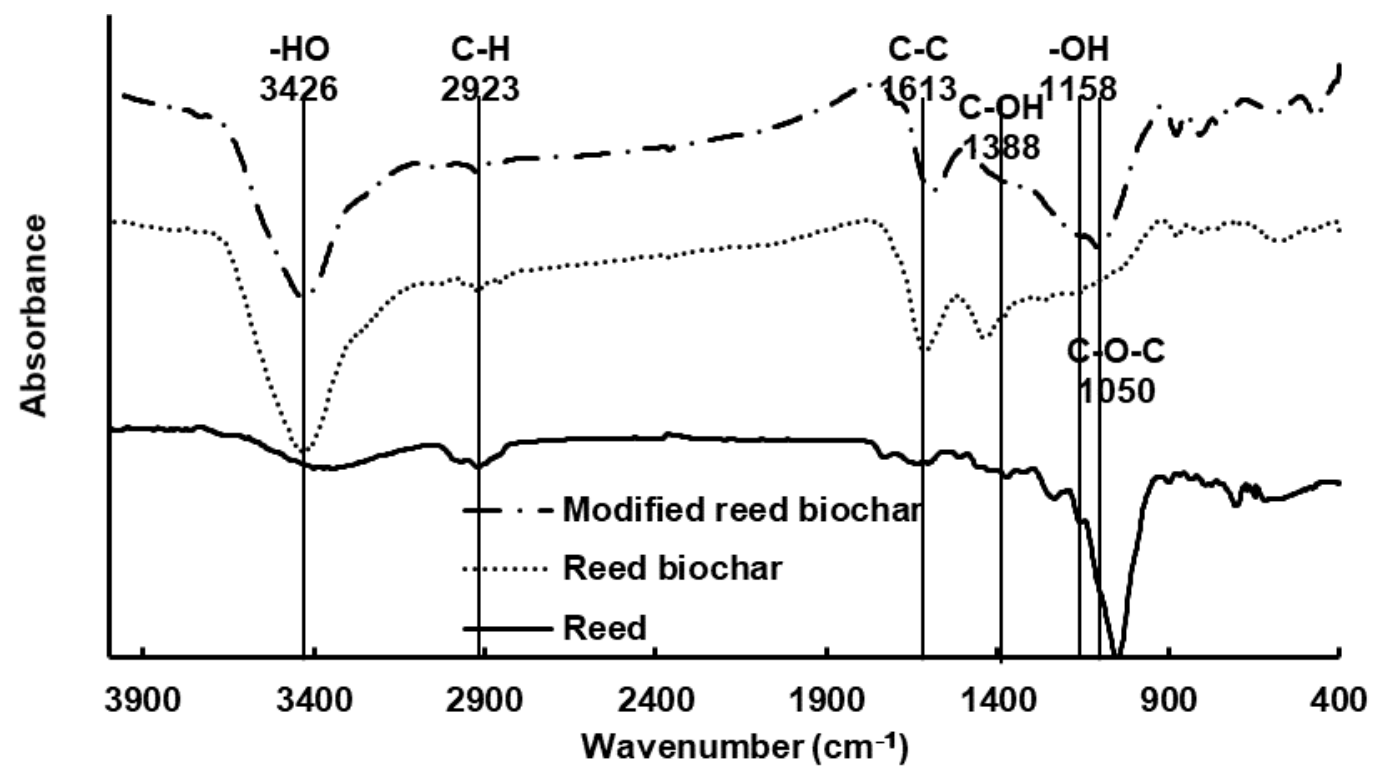

Fig. 1. FTIR spectra of reed, RBC, and MRBC.

\section{Effect of Solution pH}

Changing the solution $\mathrm{pH}$ remarkably affected the $\mathrm{Pb}$ and $\mathrm{Cd}$ sorption on both biochars (Figs. 2A and 2B). Over the $\mathrm{pH}$ range studied, the $\mathrm{Cd}$ and $\mathrm{Pb}$ sorption capacities of MRBC increased $7.5 \%$ to $41.9 \%$ and $6.4 \%$ to $59.0 \%$ compared to the RBC, with metal removal efficiencies increasing with increasing $\mathrm{pH}$. However, when the $\mathrm{pH}$ was greater than 7, the biochar metal removal rates slowed down due to dominating precipitation reactions (Inyang et al. 2012; Liang et al. 2017). Chen et al. (2015) showed that, in the presence of biochar, Cd precipitates as $\mathrm{Cd}(\mathrm{OH})_{2}$ (and $\mathrm{Pb}$ likely $\mathrm{Pb}(\mathrm{OH})_{2}$ ) when the solution $\mathrm{pH}$ is greater than 8. Similarly, Ippolito et al. (2017) noted that biochar application to acidic mine soils raises the $\mathrm{pH}$, causing $\mathrm{Pb}$ to precipitate as hydroxide phases.
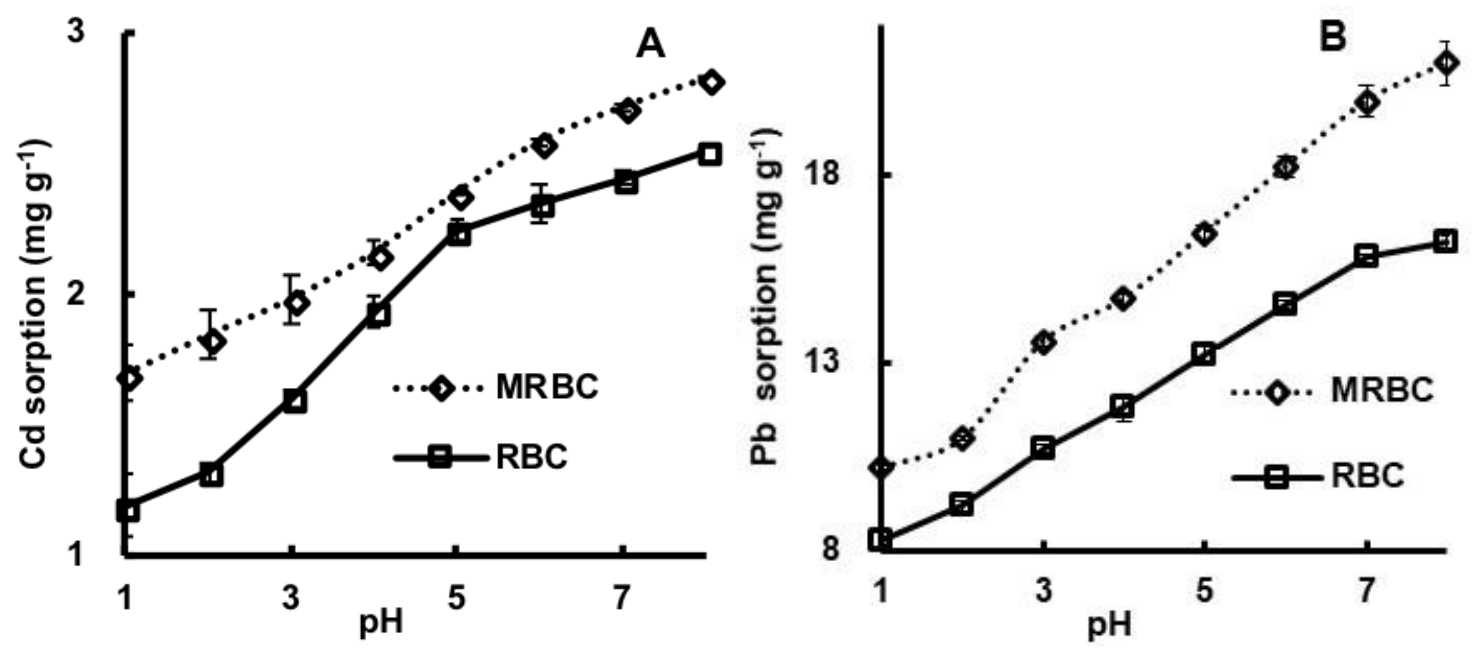

Fig. 2. Effect of $0.10 \mathrm{~g}$ from the $0.15 \mathrm{~mm}$ size-fraction of $M R B C$ and $R C B$, mixed with $50 \mathrm{~mL}$ of $0.01 \mathrm{M} \mathrm{NaNO}_{3}$ solution containing either $5 \mathrm{mg} \mathrm{Cd} \mathrm{L}^{-1}$ or $50 \mathrm{mg} \mathrm{Pb} \mathrm{L}^{-1}$ at initial pH values of 1 to 8 , on biochar $(\mathrm{A}) \mathrm{Cd}$ and $(\mathrm{B}) \mathrm{Pb}$ adsorption capacities 
Others have noted that $\mathrm{pH}$-dependent surface charge plays a vital role in improving biochar metal surface sorption through electrostatic interactions (Cui et al. 2014) and metals exchange with cations on biochar, which is commonly considered to reach equilibrium relatively quickly (e.g., $\mathrm{Ca}^{2+}, \mathrm{Mg}^{2+}$, and $\mathrm{Na}^{+}$; Lu et al. 2012; Chen et al. 2015). In addition to precipitation reactions at elevated $\mathrm{pH}$ values, oxygen-containing functional groups (e.g., carboxyl and hydroxyl) on both biochars were likely negatively charged, further enhancing $\mathrm{Cd}$ and $\mathrm{Pb}$ sorption; Ippolito et al. (2017) noted a similar $\mathrm{Cd}$ sorption response in the presence of biochar. Thus, $\mathrm{Cd}$ and $\mathrm{Pb}$ precipitation reactions and electrostatic sorption was enhanced in the MRBC via the Fe activation treatment.

\section{Effect of BC Particle Size and Dosage}

Cadmium and $\mathrm{Pb}$ solution removal rates increased as the biochar particle size decreased and following biochar activation (Figs. 3A and 3B). Cadmium removal rates ranged from $59.6 \%$ to $74.6 \%$ (RBC) and $72.9 \%$ to $95.9 \%$ (MRBC), while $\mathrm{Pb}$ removal rates ranged from $30.2 \%$ to $76.1 \%$ (RBC) and $43.6 \%$ to $88.8 \%$ (MRBC). The smaller $\mathrm{RBC}$ particle size likely contained greater surface area for the metal sorption reactions to occur. Moreover, crushed reed material activated with $\mathrm{Fe}$ from $\left(\mathrm{NH}_{4}\right)_{2} \mathrm{Fe}\left(\mathrm{SO}_{4}\right)_{2}$ likely enhanced $\mathrm{Fe}$ and $\mathrm{SO}_{4}{ }^{2-}$ loading, and in conjunction with small particles and larger surface area, made the MRBC more reactive for $\mathrm{Pb}$ and $\mathrm{Cd}$ sorption; Han et al. (2016) reported a similar observation.
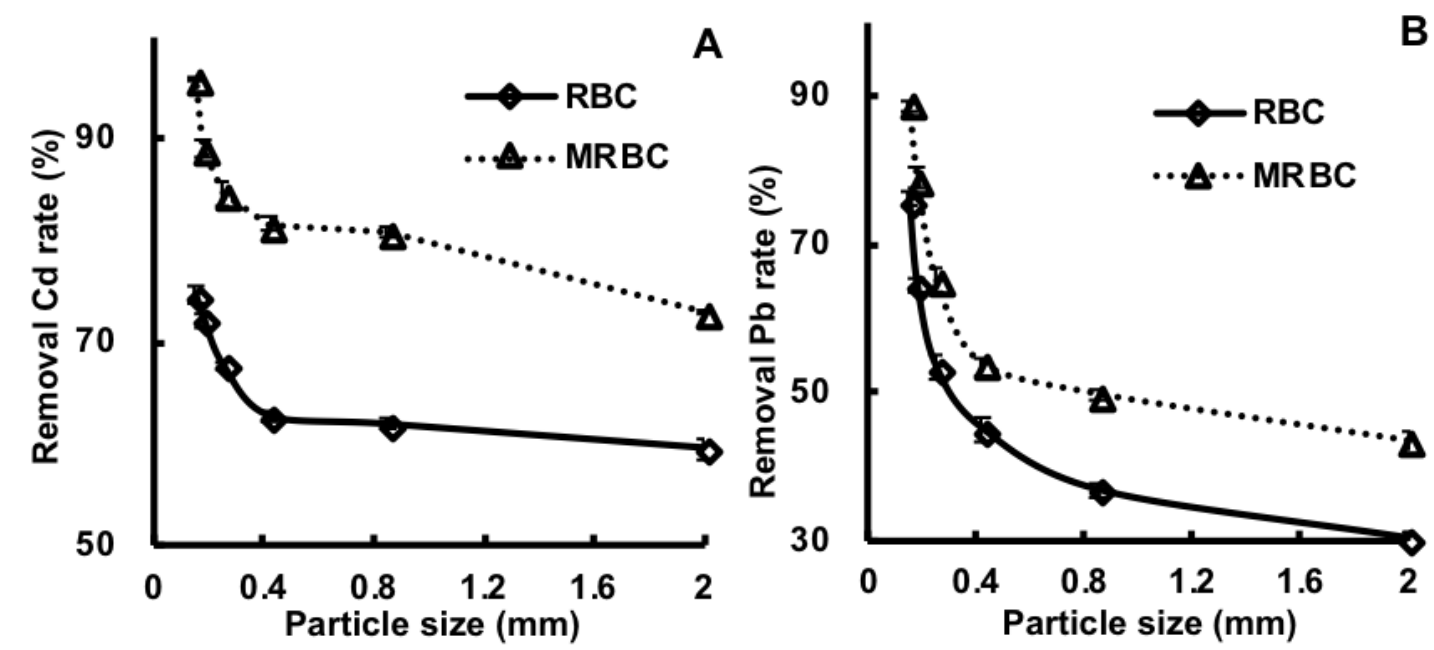

Fig. 3. Effect of $0.10 \mathrm{~g}$ of $\mathrm{MRBC}$ and $\mathrm{RBC}$ mixed with $50 \mathrm{~mL}$ of $0.01 \mathrm{M} \mathrm{NaNO}_{3}$ solution containing either $5 \mathrm{mg} \mathrm{Cd} \mathrm{L}^{-1}$ or $50 \mathrm{mg} \mathrm{Pb} \mathrm{L}^{-1}$ over biochar particle size (from 0.15 to $2 \mathrm{~mm}$ ), at a pH of $\sim 7$, on (A) $\mathrm{Cd}$ and $(\mathrm{B}) \mathrm{Pb}$ adsorption capacities

Increasing the biochar dose, at a constant initial metal concentration, increased the $\mathrm{Pb}$ and $\mathrm{Cd}$ sorption onto both the RBC and MRBC (Figs. 4A and 4B). When the biochar

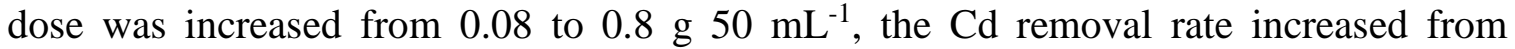
$18.2 \%$ to $86.8 \%$ (RBC) and $24.2 \%$ to $98.3 \%$ (MRBC), and the $\mathrm{Pb}$ removal rates increased from $23.9 \%$ to $83.5 \%$ (RBC) and $32.7 \%$ to $99.9 \%$ (MRBC). Increasing the biochar dosage provided greater quantities of active sites and thus greater heavy metal removal, until the removal efficiency plateaued. Furthermore, the $\mathrm{Cd}$ and $\mathrm{Pb}$ plateau was greater with MRBC likely due to $\mathrm{Fe}$ activation and a subsequent increase in surface area $(\mathrm{MRBC}>\mathrm{RBC}$; Table 1). Others have also suggested that biochar activation increases 
surface area, leading to greater metal sorption (Lima and Marshall 2005; Azargohar and Dalai 2008; Uchimiya et al. 2010).
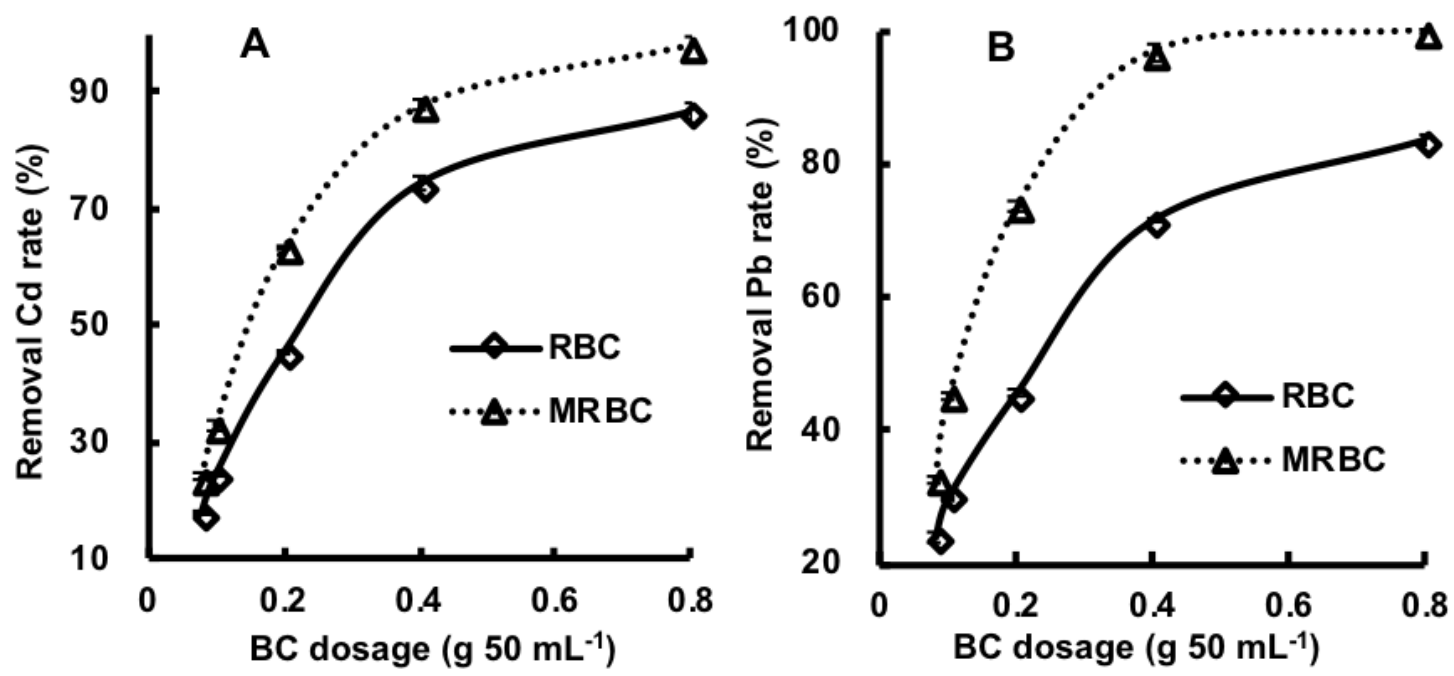

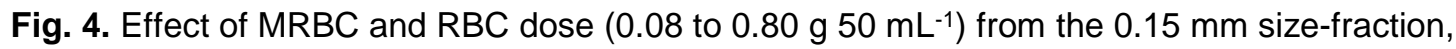
mixed with $50 \mathrm{~mL}$ of $0.01 \mathrm{M} \mathrm{NaNO}_{3}$ solution (pH approx. 7) containing either $5 \mathrm{mg} \mathrm{Cd} \mathrm{L}^{-1}$ or 50 $\mathrm{mg} \mathrm{Pb} \mathrm{L-1}$, on the removal rate of $\mathrm{Cd}(\mathrm{A})$ and $\mathrm{Pb}(\mathrm{B})$

\section{MRBC Sorption Kinetics}

The MRBC $\mathrm{Cd}$ and $\mathrm{Pb}$ pseudo-first-order and pseudo-second-order sorption kinetics as related to temperature, and the corresponding degree of fitting values, are shown in Fig. 1S and Table 2, respectively. Across all temperatures, the metal sorption linearly increased for the first approximately $60 \mathrm{~min}$, reaching a plateau after approximately $120 \mathrm{~min}$. Initial, rapid sorption (i.e., first $60 \mathrm{~min}$ ) may have been attributable to metal-hydroxyl group associations on MRBC outer surfaces. As sorption is slowed (i.e., after $60 \mathrm{~min}$ ), metal sorption likely shifts from outer to inner MRBC surfaces (Makris et al. 2005; Bogusz et al. 2015), or due to metal precipitation with Febearing activated phases. This suggests that, over time, $\mathrm{Cd}$ and $\mathrm{Pb}$ sorption onto $\mathrm{MRBC}$ is controlled by a chemisorption process involving precipitation reactions, as observed in other biochar-metals systems (Kołodyńska et al. 2012; Bogusz et al. 2015). Although not determined in the current study, one cannot rule out: 1) competitive adsorption processes existing between the same and different metals, such as observed for $\mathrm{Cd}$ and $\mathrm{Pb}$ ions (Han et al. 2017) and for $\mathrm{Pb}, \mathrm{Cd}, \mathrm{Zn}, \mathrm{Cu}, \mathrm{K}$, and $\mathrm{Na}$ (Xu et al. 2013); and 2) metal sorption as a second, third, etc., monolayer (Harter and Naidu 2001).

Temperature had an effect on $\mathrm{Cd}$ and $\mathrm{Pb}$ removal efficiency at the same initial metal ion concentrations (Fig. 1S). The increase in solution temperature, from 25 to $45^{\circ} \mathrm{C}$, led to an increase in MRBC $\mathrm{Cd}$ and $\mathrm{Pb}$ adsorption capacities. This may indicate that the adsorption process is endothermic (Jung et al. 2018). The increase in $\mathrm{Cd}$ and $\mathrm{Pb}$ removal efficiency with increasing temperature may be due to electrostatic forces between MRBC active sites and metal ions, causing increased sorption from the solution to solid biochar phase (Idrees et al. 2018).

Furthermore, greater temperatures also influenced the magnitude of the sorption correlation coefficient $\left(\mathrm{R}^{2}\right)$. Cadmium sorption onto MRBC was better fitted to the pseudo-first-order model $\left(\mathrm{R}^{2}=0.993\right.$ to 0.999$)$ than the pseudo-second-order model $\left(\mathrm{R}^{2}=\right.$ 0.966 to 0.984 ); the opposite was observed for $\mathrm{Pb}$ (pseudo-second-order: $\mathrm{R}^{2}=0.976$ to 
0.987 as compared to pseudo-first-order: $\mathrm{R}^{2}=0.936$ to 0.958 ). Pseudo-second-order fitted the data with $\mathrm{R}^{2}$ values of lower 0.999. Certainly, the higher fitting of kinetic data with the pseudo-first-order model, as temperature was increased, confirmed that $\mathrm{Cd}$ and $\mathrm{Pb}$ sorption onto biochar were not just a simple particle diffusion as in a first-order reaction (El-Banna et al. 2018).

Table 2. Constants and Correlation Coefficients of Pseudo-first-order and Pseudo-second-order Models for $\mathrm{Cd}$ and $\mathrm{Pb}$ Adsorption by MRBC

\begin{tabular}{|c|c|c|c|c|c|}
\hline Treatments & Temperature & \multicolumn{2}{|c|}{ Pseudo-first-order Model } & \multicolumn{2}{c|}{ Pseudo-second-order Model } \\
\hline \multirow{3}{*}{$\mathrm{Cd}$} & & $K_{1}$ & $\mathrm{R}^{2}$ & $K_{2}$ & $\mathrm{R}^{2}$ \\
\hline & $25^{\circ} \mathrm{C}$ & 0.037 & 0.993 & 0.019 & 0.966 \\
\cline { 2 - 6 } & $35^{\circ} \mathrm{C}$ & 0.042 & 0.996 & 0.022 & 0.976 \\
\cline { 2 - 6 } & $45^{\circ} \mathrm{C}$ & 0.044 & 0.999 & 0.024 & 0.984 \\
\hline \multirow{3}{*}{$\mathrm{Pb}$} & $25^{\circ} \mathrm{C}$ & 0.113 & 0.936 & 0.014 & 0.976 \\
\cline { 2 - 6 } & $35^{\circ} \mathrm{C}$ & 0.143 & 0.956 & 0.017 & 0.983 \\
\cline { 2 - 6 } & $45^{\circ} \mathrm{C}$ & 0.132 & 0.958 & 0.014 & 0.987 \\
\hline
\end{tabular}

\section{MRBC Adsorption Isotherms}

The Langmuir and Freundlich models were used to further investigate MRBC sorption of $\mathrm{Cd}$ and $\mathrm{Pb}$ (Fig. 2S). The Langmuir model assumes monolayer surface sorption, while the Freundlich model is used to describe chemisorption on heterogeneous surfaces (Han et al. 2016). The Langmuir model was better at explaining $\mathrm{Cd}$ and $\mathrm{Pb}$ sorption by MRBC, based on the fitted results presented in Table 3. The Langmuir findings were in good agreement with the study of Bogusz et al. (2017), who used biomass (Sida hermaphrodita and wheat straw) produced biochar to adsorb Cd and Ni. In their findings, the Langmuir model was demonstrated to be the best to describe the metal sorption. In addition, Kołodyńska et al. (2012) reported that the pig and cow manurebased biochar were very well to fit the Langmuir model during the sorption of $\mathrm{Cd}(\mathrm{II})$ ions.

Table 3. Constants and Correlation Coefficients of Langmuir and Freundlich Models for $\mathrm{Cd}$ and $\mathrm{Pb}$ Adsorption by MRBC (at $\mathrm{pH} \sim 7$ )

\begin{tabular}{|c|c|c|c|c|c|c|c|}
\hline \multirow{2}{*}{ Treatments } & \multirow{2}{*}{ Temperature } & \multicolumn{3}{|c|}{ Langmuir } & \multicolumn{3}{c|}{ Freundlich } \\
\cline { 2 - 8 } & & $K_{\mathrm{L}}$ & $Q_{\max }$ & $\mathrm{R}^{2}$ & $K_{\mathrm{F}}$ & $n$ & $\mathrm{R}^{2}$ \\
\hline \multirow{3}{*}{$\mathrm{Cd}$} & $25^{\circ} \mathrm{C}$ & 0.248 & 2.396 & 0.964 & 0.267 & 1.394 & 0.802 \\
\cline { 2 - 8 } & $35^{\circ} \mathrm{C}$ & 0.260 & 2.562 & 0.976 & 0.333 & 1.504 & 0.796 \\
\cline { 2 - 8 } & $45^{\circ} \mathrm{C}$ & 0.249 & 2.971 & 0.985 & 0.397 & 1.529 & 0.812 \\
\hline \multirow{3}{*}{$\mathrm{Pb}$} & $25^{\circ} \mathrm{C}$ & 0.151 & 15.186 & 0.999 & 6.636 & 6.035 & 0.863 \\
\cline { 2 - 8 } & $35^{\circ} \mathrm{C}$ & 0.157 & 15.842 & 0.998 & 7.003 & 6.079 & 0.839 \\
\cline { 2 - 8 } & $45^{\circ} \mathrm{C}$ & 0.170 & 17.542 & 0.999 & 7.822 & 6.068 & 0.939 \\
\hline
\end{tabular}



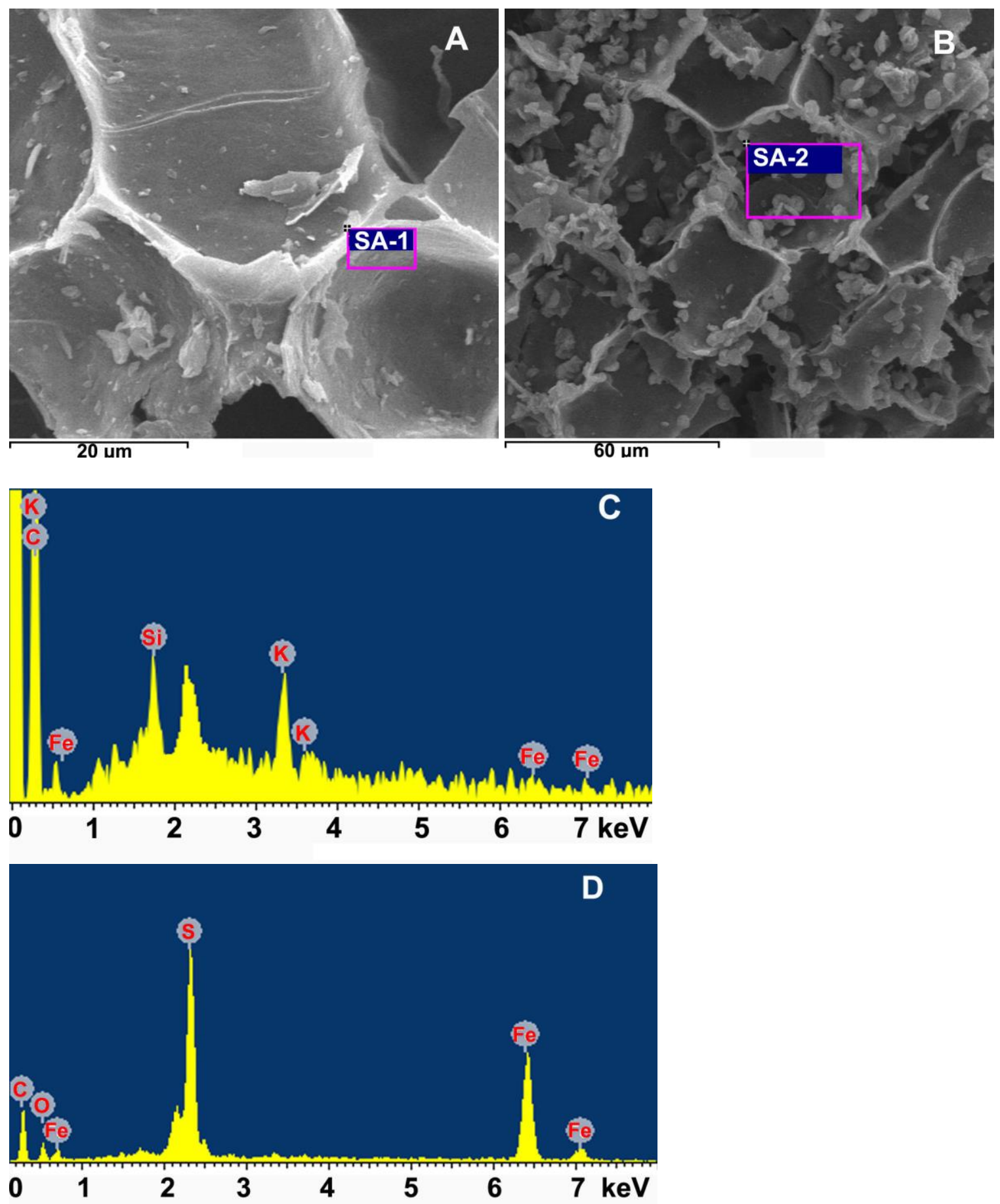

Fig. 5. SEM images of reed biochar (RBC: A) and modified reed biochar (MRBC: B); SEM-EDS spectra of RBC (C) and MRBC (D) from the areas of (SA-1) and (SA-2), respectively

As the temperature increased, the $K$ value (sorption energy) increased from 0.248 to 0.260 for $\mathrm{Cd}$ and from 0.151 to 0.170 for $\mathrm{Pb}$ (Table 3). The maximum MRBC adsorption capacity increased from $25{ }^{\circ} \mathrm{C}\left(\mathrm{Cd}, 2.40 \mathrm{mg} \mathrm{g}^{-1} ; \mathrm{Pb}, 15.19 \mathrm{mg} \mathrm{g}^{-1}\right)$ to $35{ }^{\circ} \mathrm{C}$ $\left(\mathrm{Cd}, 2.56 \mathrm{mg} \mathrm{g}^{-1} ; \mathrm{Pb}, 15.84 \mathrm{mg} \mathrm{g}^{-1}\right)$ to $45{ }^{\circ} \mathrm{C}\left(\mathrm{Cd}, 2.97 \mathrm{mg} \mathrm{g}^{-1} ; \mathrm{Pb}, 17.54 \mathrm{mg} \mathrm{g}^{-1}\right)$ for $\mathrm{Cd}$ (by $6.9 \%$ and $24.0 \%$, respectively) and for $\mathrm{Pb}$ (by $4.3 \%$ and $15.5 \%$, respectively). The isotherms showed that the $\mathrm{Cd}$ and $\mathrm{Pb}$ sorption capacities increased with higher 
temperature and initial concentration, which likely reflected a metal precipitation mechanism similar to that described by Cao et al. (2009). The increased sorption energy and maximum sorption capacity found here further supported the pseudo-first- and second-order observations previously described.

\section{RBC and MRBC Microstructure}

Large microstructural changes were observed on the MRBC surface, attributed to the ferrous ammonium sulfate $\left[\left(\mathrm{NH}_{4}\right)_{2} \mathrm{Fe}\left(\mathrm{SO}_{4}\right)_{2}\right]$ activation step. Specifically, a greater number of small particles containing appreciable quantities of $\mathrm{Fe}$ and $\mathrm{S}$ were observed on the MRBC surface, as compared to RBC, via SEM-EDS (Fig. 5B vs. Fig. 5A). The biochar $\mathrm{Fe}$ activation process likely resulted in increased surface area due to $\mathrm{Fe}$ precipitate formation across the biochar surface. The MRBC, with its surface activation and well-developed inner structure (as observed by comparing Fig. 5A to 5B), can offer the opportunity to adsorb more heavy metals such as $\mathrm{Cd}$ and $\mathrm{Pb}$ (Trakal et al. 2016). It has been suggested that Fe activation can act as a catalyst to accelerate conformational changes in biochar structure (Zhou et al. 2017), which likely occurred in the current study as well. The EDS spectra showed that $\mathrm{S}$ and Fe were more present on the MRBC than the RBC surface (Fig. 5D vs. Fig. 5C, respectively). Thus, it is not unreasonable to suggest that the small particles present in Fig. 5B contained both $\mathrm{S}$ and Fe, which developed from the biochar activation process and contributed to increased metal sorption.

\section{CONCLUSIONS}

1. Iron-activated reed biochar improved $\mathrm{Cd}$ and $\mathrm{Pb}$ sorption characteristics, such as the surface microstructure and elements content.

2. The biochar $\mathrm{Fe}$ activation treatment $\left[\left(\mathrm{NH}_{4}\right)_{2} \mathrm{Fe}\left(\mathrm{SO}_{4}\right)_{2}\right]$ improved the presence of functional groups and microstructure surface area on MRBC, leading to enhanced $\mathrm{Cd}$ and $\mathrm{Pb}$ max sorption capacities as $2.97 \mathrm{mg} \mathrm{g}^{-1}$ and $17.5 \mathrm{mg} \mathrm{g}^{-1}$ at $45{ }^{\circ} \mathrm{C}$ on the MRBC.

3. The biochar adsorption capacities on $\mathrm{Cd}$ and $\mathrm{Pb}$ were affected by many factors. For example, the removal rate was increased to $86.8 \%$ (RBC) and 98.3\% (MRBC) with

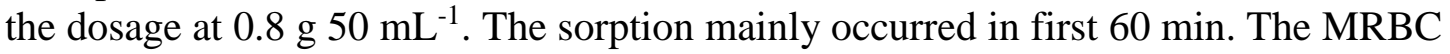
sorption capacity values were increased as $41.9 \%(\mathrm{Cd})$ and $59.0 \%(\mathrm{~Pb})$ at the $\max$ initial $\mathrm{pH}$. The $\mathrm{Cd}$ and $\mathrm{Pb}$ removal rates were $74.6 \%$ and $76.1 \%$ on $\mathrm{RBC}$ and $95.9 \%$ and $88.8 \%$ on MRBC at $0.15 \mathrm{~mm}$ biochar.

4. Modified reed biomass biochar has the potential to be used as an efficient and ecofriendly $\mathrm{Cd}$ and $\mathrm{Pb}$ sorbent, and in the future may help reduce water-borne issues associated with metal contamination.

\section{ACKNOWLEDGMENTS}

This study was supported by the National Natural Science Foundation of China under Grant Nos. 41501339, 21677119, 41501353, and 41301551, and the Natural Science Foundation of Jiangsu Province for Youths under Grant No. BK20140468, as well as the Qing Lan Project. 


\section{REFERENCES CITED}

Azargohar, R., and Dalai, A. (2008). "Steam and KOH activation of biochar:

Experimental and modeling studies," Micropor. Mesopor. Mat. 110(2-3), 413-421.

DOI: 10.1016/j.micromeso.2007.06.047

Bogusz, A., Nowak, K., Stefaniuk, M., Dobrowolski, R., and Oleszczuk, P. (2017).

"Synthesis of biochar from residues after biogas production with respect to cadmium and nickel removal from wastewater," J. Environ. Manage. 201, 268-276. DOI: 10.1016/j.jenvman.2017.06.019

Bogusz, A., Oleszczuk, P., and Dobrowolski, R. (2015). "Application of laboratory prepared and commercially available biochars to adsorption of cadmium, copper and zinc ions from water," Bioresource Technol. 196, 540-549. DOI:

10.1016/j.biortech.2015.08.006

Bolognesi, C., Landini, E., Roggieri, P., Fabbri, R., and Viarengo, A. (1999).

"Genotoxicity biomarkers in the assessment of heavy metal effects in mussels: Experimental studies," Environ. Mol. Mutagen. 33(4), 287-292. DOI: 10.1002/(SICI)1098-2280(1999)33:4<287::AID-EM5>3.0.CO;2-G

Cao, X., Ma, L., Gao, B., and Harris, W. (2009). "Dairy-manure derived biochar effectively sorbs lead and atrazine," Environ. Sci. Technol. 43(9), 3285-3291. DOI: $10.1021 / \mathrm{es} 803092 \mathrm{k}$

Chen, T., Zhou, Z., Han, R., Meng, R., Wang, H., and Lu, W. (2015). “Adsorption of cadmium by biochar derived from municipal sewage sludge: Impact factors and adsorption mechanism," Chemosphere 134, 286-293. DOI: 10.1016/j.chemosphere.2015.04.052

Cui, L., Yan, J., Yang, Y., Li, L., Quan, G., Ding, C., Chen, T., Fu, Q., and Chang, A. (2013). "Influence of biochar on microbial activities of heavy metals contaminated paddy fields," BioResources 8(4), 5536-5548. DOI: 10.15376/biores.8.4.5536-5548

Cui, L., Yan, J., Yang, Y., Li, L., Quan, G., Ding, C., Chen, T., Yin, C., Gao, J., and Hussain, Q. (2014). "Does biochar alter the speciation of $\mathrm{Cd}$ and $\mathrm{Pb}$ in aqueous solution?," BioResources 10(1), 88-104. DOI: 10.15376/biores.10.1.88-104

El-Banna, M. F., Mosa, A., Gao, B., Yin, X., Ahmad, Z., and Wang, H. (2018). “Sorption of lead ions onto oxidized bagasse-biochar mitigates $\mathrm{Pb}$-induced oxidative stress on hydroponically grown chicory: Experimental observations and mechanisms," Chemosphere 208, 887-898. DOI:10.1016/j.chemosphere.2018.06.052

Han, L., Qian, L., Liu, R., Chen, M., Yan, J., and Hu, Q. (2017). "Lead adsorption by biochar under the elevated competition of cadmium and aluminum," Sci. Rep.-UK 7, Article ID 2264. DOI: 10.1038/s41598-017-02353-4

Han, Y., Cao, X., Ouyang, X., Sohi, S. P., and Chen, J. (2016). "Adsorption kinetics of magnetic biochar derived from peanut hull on removal of $\mathrm{Cr}$ (VI) from aqueous solution: Effects of production conditions and particle size," Chemosphere 145, 336341. DOI: $10.1016 /$ j.chemosphere.2015.11.050

Harada, M. (1995). "Minamata disease: Methylmercury poisoning in Japan caused by environmental pollution," Crit. Rev. Toxicol. 25(1), 1-24. DOI: $10.3109 / 10408449509089885$

Harter, R. D., and Naidu, R. (2001). "An assessment of environmental and solution parameter impact on trace-metal sorption by soils," Soil Sci. Soc. Am. J. 65(3), 597612. DOI: $10.2136 /$ sssaj2001.653597x 
Idrees, M., Batool, S., Ullah, H., Hussain, Q., Al-Wabel, M. I., Ahmad, M., Hussain, A., Riaz, M., Ok, Y.S., and Kong, J. (2018). "Adsorption and thermodynamic mechanisms of manganese removal from aqueous media by biowaste-derived biochars," J. Mol. Liq. 266, 373-380. DOI:10.1016/j.molliq.2018.06.049

Inaba, T., Kobayashi, E., Suwazono, Y., Uetani, M., Oishi, M., Nakagawa, H., and Nogawa, K. (2005). "Estimation of cumulative cadmium intake causing itai-itai disease,” Toxicol. Lett. 159(2), 192-201. DOI: 10.1016/j.toxlet.2005.05.011

Inyang, M., Gao, B., Yao, Y., Xue, Y. W., Zimmerman, A. R., Pullammanappallil, P., and Cao, X. D. (2012). "Removal of heavy metals from aqueous solution by biochars derived from anaerobically digested biomass," Bioresource Technol. 110, 50-56. DOI: 10.1016/j.biortech.2012.01.072

Ippolito, J., Berry, C., Strawn, D., Novak, J., Levine, J., and Harley, A. (2017). "Biochars reduce mine land soil bioavailable metals," J. Environ. Qual. 46(2), 411-419. DOI: 10.2134/jeq2016.10.0388

Ippolito, J., Strawn, D., Scheckel, K., Novak, J., Ahmedna, M., and Niandou, M. (2012). "Macroscopic and molecular investigations of copper sorption by a steam-activated biochar,” J. Environ. Qual. 41(4), 1150-1156. DOI: 10.2134/jeq2011.0113

Johansson, C. L., Paul, N. A., De Nys, R., and Roberts, D. A. (2016). “Simultaneous biosorption of selenium, arsenic and molybdenum with modified algal-based biochars," J. Environ. Manage. 165, 117-123. DOI: 10.1016/j.jenvman.2015.09.021

Jung, K. W., Lee, S. Y., and Lee, Y. J. (2018). "Hydrothermal synthesis of hierarchically structured birnessite-type $\mathrm{MnO}_{2} /$ biochar composites for the adsorptive removal of $\mathrm{Cu}$ (II) from aqueous media," Bioresource Technol. 260, 204-212. DOI:10.1016/j.biortech.2018.03.125

Kan, T., Strezov, V., and Evans, T. J. (2016). "Lignocellulosic biomass pyrolysis: A review of product properties and effects of pyrolysis parameters," Renew. Sust. Energ. Rev. 57, 1126-1140. DOI: 10.1016/j.rser.2015.12.185

Karunanayake, A. G., Todd, O. A., Crowley, M., Ricchetti, L., Pittman Jr, C.U., Anderson, R., Mohan, D., and Mlsna, T. (2018). "Lead and cadmium remediation using magnetized and nonmagnetized biochar from Douglas fir," Chem. Eng. J. 331, 480-491. DOI:10.1016/j.cej.2017.08.124

Khan, S., Cao, Q., Zheng, Y. M., Huang, Y. Z., and Zhu, Y. G. (2008). "Health risks of heavy metals in contaminated soils and food crops irrigated with wastewater in Beijing, China," Environ. Pollut. 152(3), 686-692. DOI:

10.1016/j.envpol.2007.06.056

Khan, S., Reid, B. J., Li, G., and Zhu, Y. G. (2014). "Application of biochar to soil reduces cancer risk via rice consumption: A case study in Miaoqian village, Longyan, China," Environ. Int. 68, 154-161. DOI: 10.1016/j.envint.2014.03.017

Kim, I. J., Kim, R. Y., Kim, J. I., Kim, H. S., Noh, H. J., Kim, T. S., Yoon, J. K., Park, G. H., Ok, Y. S., and Jung, H. S. (2015). "Feasibility study of different biochars as adsorbent for cadmium and lead," Korean J. Soil Sci. Fert. 48(5), 332-339. DOI: 10.7745/KJSSF.2015.48.5.332

Kołodyńska, D., Wnętrzak, R., Leahy, J. J., Hayes, M. H. B., Kwapiński, W., and Hubicki, Z. (2012). "Kinetic and adsorptive characterization of biochar in metal ions removal," Chem. Eng. J. 197, 295-305. DOI: 10.1016/j.cej.2012.05.025

Liang, J., Li, X., Yu, Z., Zeng, G., Luo, Y., Jiang, L., Yang, Z., Qian, Y., and Wu, H. (2017). "Amorphous $\mathrm{MnO}_{2}$ modified biochar derived from aerobically composted 
swine manure for adsorption of Pb (II) and Cd (II)," ACS Sustain. Chem. Eng. 5(6), 5049-5058. DOI: 10.1021/acssuschemeng.7b00434

Lima, I. M., and Marshall, W. E. (2005). "Adsorption of selected environmentally important metals by poultry manure-based granular activated carbons," J. Chem. Technol. Biot. 80(9), 1054-1061. DOI: 10.1002/jctb.1283

Lu, H., Zhang, W., Yang, Y., Huang, X., Wang, S., and Qiu, R. (2012). "Relative distribution of $\mathrm{Pb}^{2+}$ sorption mechanisms by sludge-derived biochar," Water Res. 46(3), 854-862. DOI: 10.1016/j.watres.2011.11.058

Lu, R. (2000). "Methods of inorganic pollutants analysis," Soil and Agro-chemical Analysis Methods, China Agriculture Science Press, Beijing, China, pp. 205-266

Makris, K. C., Harris, W. G., O'Connor, G. A., Obreza, T. A., and Elliott, H. A. (2005). "Physicochemical properties related to long-term phosphorus retention by drinkingwater treatment residuals," Environ. Sci. Technol. 39(11), 4280-4289. DOI: 10.1021/es0480769

Mohan, D., Sarswat, A., Ok, Y. S., and Pittman, C. U. (2014). "Organic and inorganic contaminants removal from water with biochar, a renewable, low cost and sustainable adsorbent-A critical review," Bioresource Technol. 160, 191-202. DOI: 10.1016/j.biortech.2014.01.120

Qian, L., Zhang, W., Yan, J., Han, L., Gao, W., Liu, R., and Chen, M. (2016). "Effective removal of heavy metal by biochar colloids under different pyrolysis temperatures," Bioresource Technol. 206, 217-224. DOI: 10.1016/j.biortech.2016.01.065

Qiao, Y., Crowley, D., Wang, K., Zhang, H., and Li, H. (2015). "Effects of biochar and Arbuscular mycorrhizae on bioavailability of potentially toxic elements in an aged contaminated soil," Environ. Pollut. 206, 636-643. DOI:

10.1016/j.envpol.2015.08.029

Roberts, K. G., Gloy, B. A., Joseph, S., Scott, N. R., and Lehmann, J. (2010). "Life cycle assessment of biochar systems: Estimating the energetic, economic, and climate change potential," Environ. Sci. Technol. 44(2), 827-833. DOI: 10.1021/es902266r

Singh, V., Ram, C., and Kumar, A. (2016). "Physico-chemical characterization of electroplating industrial effluents of Chandigarh and Haryana Region," J. Civil Environ. Eng. 6, 2-6. DOI: 10.4172/2165-784X.1000237

Trakal, L., Veselská, V., Šafařík, I., Vítková, M., Číhalová, S., and Komárek, M. (2016). "Lead and cadmium sorption mechanisms on magnetically modified biochars," Bioresource Technol. 203, 318-324. DOI: 10.1016/j.biortech.2015.12.056

Uchimiya, M., Lima, I. M., Klasson, K. T., Chang, S., Wartelle, L. H., and Rodgers, J. E. (2010). "Immobilization of heavy metal ions $\left(\mathrm{Cu}^{\mathrm{II}}, \mathrm{Cd}^{\mathrm{II}}, \mathrm{Ni}^{\mathrm{II}}\right.$, and $\left.\mathrm{Pb}^{\mathrm{II}}\right)$ by broiler litter-derived biochars in water and soil," J. Agr. Food. Chem. 58(9), 5538-5544. DOI: $10.1021 / \mathrm{jf} 9044217$

Wang, H., Gao, B., Wang, S., Fang, J., Xue, Y., and Yang, K. (2015). “Removal of Pb (II), $\mathrm{Cu}$ (II), and $\mathrm{Cd}$ (II) from aqueous solutions by biochar derived from $\mathrm{KMnO}_{4}$ treated hickory wood," Bioresource Technol. 197, 356-362. DOI: 10.1016/j.biortech.2015.08.132

Wang, S., Gao, B., Li, Y., Creamer, A. E., and He, F. (2017). “Adsorptive removal of arsenate from aqueous solutions by biochar supported zero-valent iron nanocomposite: Batch and continuous flow tests," J. Hazard. Mater. 322, 172-181. DOI: 10.1016/j.jhazmat.2016.01.052

Wang, Z., Shen, D., Shen, F., and Li, T. (2016a). "Phosphate adsorption on lanthanum loaded biochar," Chemosphere 150, 1-7. DOI: 10.1016/j.chemosphere.2016.02.004 
Xu, X., Cao, X., and Zhao, L. (2013). "Comparison of rice husk-and dairy manurederived biochars for simultaneously removing heavy metals from aqueous solutions: Role of mineral components in biochars," Chemosphere 92(8), 955-961. DOI: 10.1016/j.chemosphere.2013.03.009

Zheng, H., Wang, Z., Deng, X., Zhao, J., Luo, Y., Novak, J., Stephen, H., and Xing, B. (2013). "Characteristics and nutrient values of biochars produced from giant reed at different temperatures," Bioresource Technol. 130, 463-471. DOI: 10.1016/j.biortech.2012.12.044

Zhou, N., Chen, H., Xi, J., Yao, D., Zhou, Z., Tian, Y., and Lu, X. (2017). "Biochars with excellent $\mathrm{Pb}$ (II) adsorption property produced from fresh and dehydrated banana peels via hydrothermal carbonization," Bioresource Technol. 232, 204-210. DOI: 10.1016/j.biortech.2017.01.074

Article submitted: August 15, 2018; Peer review completed: October 28, 2018; Revised version received: November 4, 2018; Accepted: November 22, 2018; Published:

December 6, 2018.

DOI: $842-857$ 


\section{SUPPLEMENTARY INFORMATION}
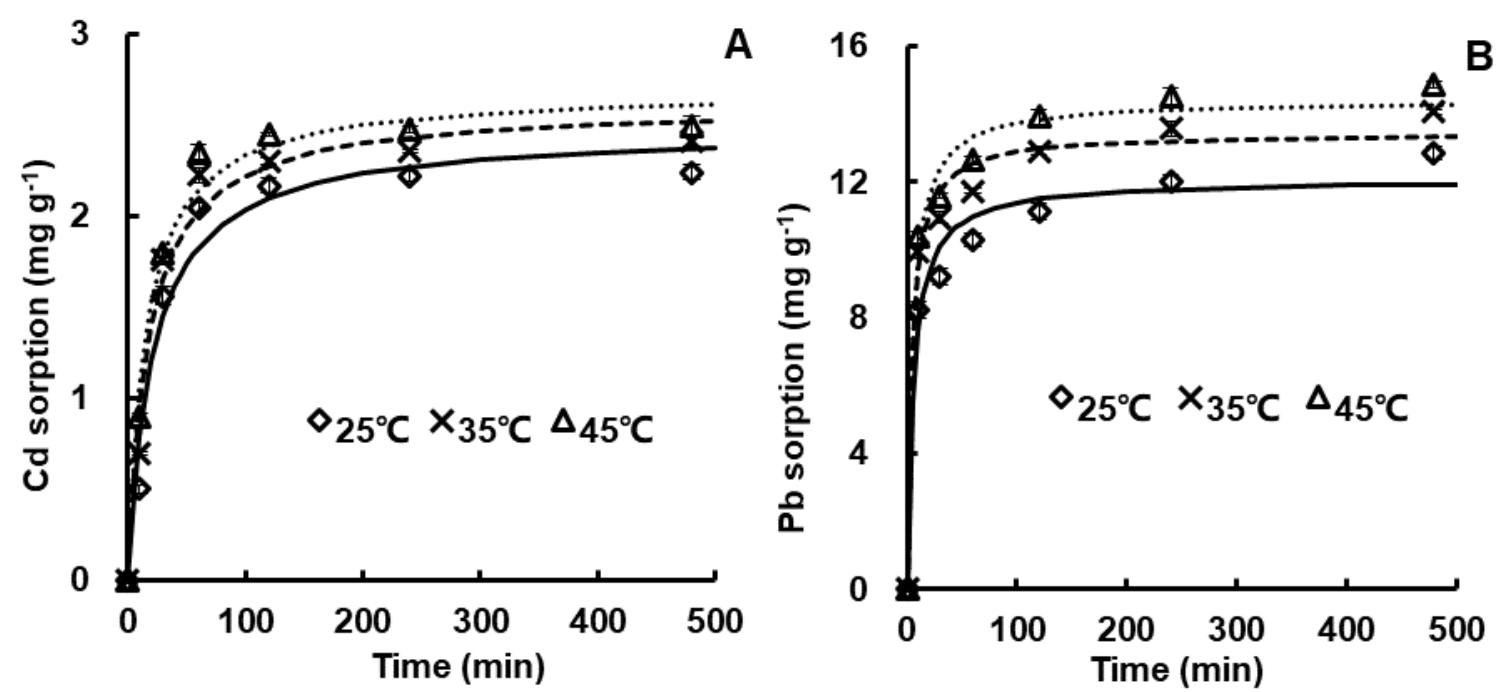

Fig. 1S. Adsorption kinetics of $\mathrm{Cd}(\mathrm{A})$ and $\mathrm{Pb}(\mathrm{B})$ onto MRBC following pseudo-second-order model
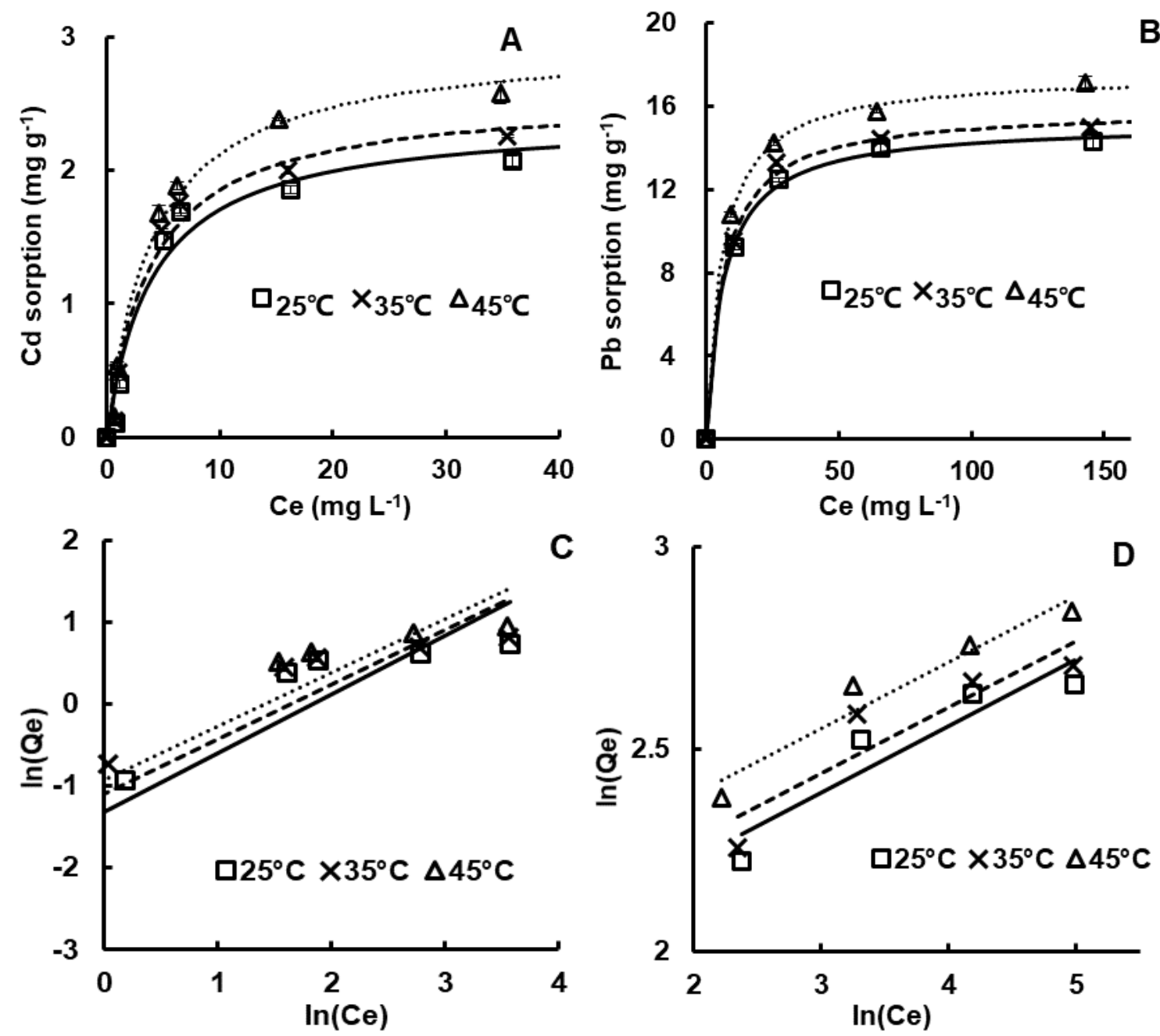

Fig. 2S. Sorption isotherms of $(A, C) C d$ and $(B, D) P b$ by MRBC with Langmuir $(A, B)$ and Freundlich $(C, D)$ model at different temperatures 